\title{
MEASUREMENT OF HEAT LOSSES ON THE MILKING MACHINE ELECTRIC MOTOR AT VARIOUS REGULATIONS OF VACUUM USING METHODS OF THERMAL IMAGERY
}

\author{
Jan Kudělka ${ }^{1}$, Jiří Fryčํ, Petr Trávníček ${ }^{1}$ \\ ${ }^{1}$ Department of Agriculture, Food and Environmental Engineering, Mendel University in Brno, Zemědělská 1, \\ 61300 Brno, Czech Republic
}

\begin{abstract}
KUDĚLKAJAN, FRYČ JIŘÍ, TRÁVNÍČEK PETR. 2014. Measurement of Heat Losses on The Milking Machine Electric Motor at Various Regulations of Vacuum Using Methods of Thermal Imagery. Acta Universitatis Agriculturae et Silviculturae Mendelianae Brunensis, 62(5): 1007-1014.

To ensure the desirable vacuum in the milking machines, use is currently made predominantly of rotary vacuum pumps. These vacuum pumps are driven by a squirrel-cage induction motor. Until recently, the vacuum in the system to achieve the required value was controlled by a main control valve sucking in ambient air into the system. During the milking process itself and during other activities (flushing, sanitation), this control method consumed a large amount of electricity. The technical solution to electricity demand reduction was introduced with the emergence and development of frequency converters. The frequency converters control the operation of the asynchronous electric motor so that the actual delivery of the vacuum pumps equals the volume of air sucked into the vacuum pipe. The motor supply by the frequency converter brings about a host of adverse phenomena. This paper is dedicated to motor heating and heat losses on the surface of the electric motor at different regulations of vacuum in milking machines. The objective of the paper is to determine the immediate specific heat flows along the surface of the electric motor of the milking machine during milking using a control valve regulation and a control using the frequency converter, and compare the resulting value. The specific heat flows were determined by means of a non-traditional method of temperature field measurement using a system of thermal imagery. The calculated and measured data obtained from both these systems were statistically evaluated and compared. Use was made of a milking machine located in the cooperative Hospodářské obchodní družstvo (HOD) Jabloňov.
\end{abstract}

Keywords: milking machine, rotary vacuum pump, electric motor, control valve, frequency converter, thermal camera, heat losses

\section{INTRODUCTION}

The milking machine and the mechanical milking process itself rightly receive great attention as this activity requires a mutual interaction between man, animal and machine. The individual elements of this so-called "biotechnical system" must work in a mutual cooperation. For this reason, the milking machine is fitted with sensors monitoring and controlling processes in livestock production. The correct performance of the milking machine is set in the milking process through the monitoring of milk flow, conductivity, milk yield, somatic cell count in milked milk and other parameters (Berckmans, 2004).

For the required performance of the milking machine it is most important to ensure a stable and constant vacuum. Vacuum in the system is ensured by the vacuum pump, which is the basic mechanical element of the milking machine (Ströbel, 2013). The vacuum pump is driven by a squirrel-cage induction motor. Currently, vacuum in the milking system is mainly generated by a rotary vane suction pump sucking in air at a lower pressure 
than the ambient air pressure and compressing the air to a pressure slightly above the ambient air pressure (Groda, Vítěz, 2008).

The rotary vane vacuum pump consists of a cylindrical rotor with deep grooves, in which the vanes move. The rotor is set eccentrically to the stator in which it rotates. The rotation-induced normal acceleration shifts the vanes towards the internal surface of the stator. The sickle-shaped space between the cylinder, rotor and two adjacent vanes changes during the rotation. When the rotor turns, the chamber volume expands and sucks in gas from the air pipe. The vacuum is generated in the air pipe. When the vanes travel over the edge of the groove, the connection with the suction is interrupted, the chamber volume starts decreasing and gas pressure rises. The compression stops when the front vane travels over the edge of the delivery outlet and the chamber gets connected with the delivery space (Fryč, 2000). The set of the vacuum pump driven by a squirrel-cage induction motor must be able to cover the operating demands (milking, flushing and sanitation), which are in a continuous or intermittent operation. The values of the required vacuum $(40-50 \mathrm{kPa})$ in the air pipe of the milking machine and the theoretical delivery of the vacuum pump are set by a Czech technical standard (ČSN ISO 5707). Vacuum regulation to desirable values defined by the standard has been until recently ensured solely by the correctly set control valve. This valve operates by sucking the ambient air from the ambient environment into a pipe with a lower pressure than the ambient pressure (Přikryl et al., 1997). However, the asynchronous motor driving the rotary vane vacuum pump works at full power input. As a result, the milking process itself consumes more electricity. In technical terms, it was necessary to ensure a stable vacuum in the system at optimum operating parameters of the asynchronous motor, including motor revolutions, torque and electricity demand (Doležal et al., 2000). To provide for this, the principle of frequency converter can be employed, which makes it possible to control the revolutions to the required values. This would reduce the total electricity consumption (Kolarčík, Vrtek, 2002). Thus, the regulation system using a frequency converter would reduce the consumption of electricity by making sure that the vacuum pump only extracts the air that was produced in the milking machine at optimum operating parameters of the electric motor (Reinnemann et al., 2005).

The objective of this paper is to monitor, at specifically set input parameters of the frequency converter (and given a stable vacuum and minimum electricity consumption), the temperature changes depending on time. It is necessary to calculate immediate specific heat losses in the electric motor of the milking machine by means of a thermocouple and methods of thermal imagery. It is also necessary to compare and statistically evaluate the functional temperature and heat dependences during classic regulation and regulation using a frequency converter. After that, we will validate whether the effect of reducing the number of revolutions, resulting in a reduced air flow through the ribbing, lead to the electric motor overheating and whether it is then necessary to propose potential ancillary cooling.

\section{METHODS AND MATERIALS}

To address the matter, use was made of a milking machine located in the cooperative Hospodářské obchodní družstvo (HOD) in Jabloňov. The HOD is fitted with a six-place tandem milking parlour $(2 \times 3)$. The system of vacuum pumps consists of two rotary vane vacuum pumps designated as SVL 1264-15-67 with a theoretical delivery of $20 \mathrm{~m}^{3} \cdot \mathrm{h}^{-1}$ and $41.4 \mathrm{~m}^{3} \cdot \mathrm{h}^{-1}$, driven by a single squirrel-cage induction motor by Siemens with a theoretical output of $4 \mathrm{~kW}$. A frequency converter Siemens Sinamics G120P BT with a high-performance SINAMICS PM 230 unit was installed in the cooperative in order to validate the operation of the vacuum sensor SIEMANS SITRANS P. The input parameters were correctly set in the installed frequency converter so that the el. power consumption was minimum at the constant vacuum values.

To measure heat losses and to subsequently determine the temperature dependences and heat flux at various vacuum regulations in the asynchronous motor, we used a digital temperature meter Omega $\mathrm{HHll}$ with a touch sensor (measurement accuracy $\pm 0.1^{\circ} \mathrm{C}$ ) and thermal camera Model FLIR E320 made in United States. Air temperature and humidity were measured by means of a thermo-hygrometer OMEGA RH81 with temperature measurement accuracy of $\pm 1{ }^{\circ} \mathrm{C}$ and humidity measurement accuracy of $\pm 4 \%$ (at a temperature of $25^{\circ} \mathrm{C}$ and a range of relative humidity from 10-90 \%). Both temperature and humidity were measured in the immediate vicinity of the thermal camera and the asynchronous electric motor. The thermovisual measurement was conducted at a constant distance from the asynchronous electric motor. The distance of the camera from the asynchronous motor was $1.01 \mathrm{~m}$. This distance was set by a laser distance meter Leica DISTO ${ }^{\mathrm{tm}}$ (measurement accuracy $\pm 1.5 \mathrm{~mm}$ ). Three reference points and an area with the most intensive heat transfer were selected on the cladding of the electric motor passive cooling. The selection of these points and areas was made with respect to the fact that the direction of the notional infrared radiation vector should be perpendicular to the thermal camera sensor. The first reference point was fitted with a touch sensor of a digital thermometer. To determine the radiator emissivity, the reference point was also monitored by the thermal camera. Based on the temperature readings from the two instruments, we identified the difference between 
the values. This difference in temperatures was evened up by means of the emissivity setting in the user interface of the thermal camera. Final emissivity was determined only after the temperature values at the beginning of the measurement in both devices had become equal. In this case, the radiator emissivity amounted to $\varepsilon_{z}=0.89$. The emissivity of the ambient environment was determined using table values on the basis of average temperature and humidity of the ambient environment during the measurement (Staley, 1972). Calculations made for this project considered the ambient environment emissivity of $\varepsilon_{a}=0.71$.

Following the thermal camera calibration and preparation of the measuring station, the milking machine was activated where the vacuum in the air pipe was first regulated by a control valve. The electric motor was operated at full power input. In the course of 112 minutes, air temperature, relative humidity, temperature of the reference points and average temperature were measured and recorded every 120 seconds. The milking machine was switched off and the electric motor was then cooled down so as to achieve the initial temperatures of the measuring instrument. Identical measurement and temperature recording took place on the surface of the electric motor when the vacuum was regulated by the frequency converter.

To determine the functional temperature differences and to calculate pressure losses of the electric motor, use was made of a thermo graphic system. The thermo-visual measurements were used to read the temperatures for each pixel of the scanning thermography. The temperature of the relevant surface was calculated by means of the software ThermaCAM QuickReport, where each pixel of the video record was assigned a single temperature value. Based on the measured temperature, the MS EXCEL spreadsheet processor was employed to calculate the heat loss (through convection and radiation) for the relevant pixel representing the monitored surface on the electric motor. The sum of all partial surfaces then equals the total heat loss of the monitored part of the electric motor.

The behaviour of temperature changes and heat losses was statistically assessed by means of regression analysis. The determination coefficients $\left(R^{2}\right)$ explain the percentage of variability (reliability) of the curves and are calculated as follows (1).

$$
R^{2}=1-\frac{\sum_{i=1}^{N}\left(y_{i}-y\left(x_{i}\right)\right)^{2}}{\sum_{i=1}^{N}\left(y_{i}-m(y)\right)^{2}},
$$

where

$y\left(x_{i}\right)$.....function used to level out the curve values, $m(y)$......mean of the $y$ variable.
To calculate heat losses caused by convection, we determined the free convection coefficient along the wall of the electric motor reference surface according to McAdams, C. King and Michijev (Bašta, 2000),

according to McAdams:

$a_{k}=1.78 \times \Delta t^{0.12} \quad\left[\mathrm{~W} \cdot \mathrm{m}^{-2} \cdot \mathrm{K}^{-1}\right]$,

according to C. King:

$a_{k}=1.51 \times \Delta t^{0.33} \quad\left[\mathrm{~W} \cdot \mathrm{m}^{-2} \cdot \mathrm{K}^{-1}\right]$,

according to F. Michejev:

$a_{k}=1.55 \times \Delta t^{0.33} \quad\left[\mathrm{~W} \cdot \mathrm{m}^{-2} \cdot \mathrm{K}^{-1}\right]$.

The results described by these authors were then compared and the specific heat losses caused by convection at various vacuum regulations were then calculated according to the following similarity relation:

$q_{t}=a_{k} \times\left(t_{1}-t_{2}\right) \quad\left[\mathrm{W} \cdot \mathrm{m}^{-2}\right]$,

where

$\alpha_{k}$..........convection coefficient along the electric motor wall $\left[\mathrm{W} \cdot \mathrm{m}^{-2} \cdot \mathrm{K}^{-1}\right]$,

$t_{1}$...........air temperature $\left[{ }^{\circ} \mathrm{C}\right]$,

$t_{2} \ldots . . . . . .$. average temperature of the monitored surface of the electric motor $\left[{ }^{\circ} \mathrm{C}\right]$.

The total intensity of grey body radiation was calculated according to Stefan-Boltzmann law. The total intensity of ambient environment radiation was deducted from the total intensity of grey body radiation (reference surface of the electric motor). The calculation to determine the heat losses of the electric motor is as follows:

$I=\left(\sigma \times \varepsilon_{s} \times T_{s}^{4}\right)-\left(\sigma \times \varepsilon_{t} \times T_{t}^{4}\right) \quad\left[\mathrm{W} \cdot \mathrm{m}^{-2}\right]$,

where

$\varepsilon_{s}$..........grey body emissivity [-],

$\varepsilon_{t}$...........ambient environment emissivity [-],

$T_{s}$..........thermodynamic temperature of the grey body $[\mathrm{K}]$,

$T_{t}$.........thermodynamic temperature of the ambient environment [K],

$\sigma$..........Stefan-Boltzmann constant [W. $\left.\mathrm{m}^{-2} \cdot \mathrm{K}^{-4}\right]$.

Total heat losses of the monitored reference surface on the electric motor in HOD Jabloňov were calculated based on the following similarity relation:

$Q=S \times\left(I+q_{t}\right) \quad[\mathrm{W}]$,

where

I...........intensity of grey body radiation [W. $\left.\mathrm{m}^{-2}\right]$,

S.........total monitored (reference) surface of the electric motor $\left[\mathrm{m}^{2}\right]$,

$q_{1}$...........heat losses caused by convection $\left[\mathrm{W} \cdot \mathrm{m}^{-2}\right]$. 


\section{RESULTS AND DISCUSSION}

Based on the previous measurements it was demonstrated that a correctly set frequency converter Siemens Sinamics G120P BT reduces the average consumption of electricity of the milking machine while keeping the stability of vacuum in the air pipe (Kudělka, Fryč, 2012). A question remains whether the el. power consumption reduction by controlling the revolutions has a negative impact on the asynchronous motor overheating. A change in the machine el. supply via the frequency converter entails also a change in the distribution of heat flows in the individual parts of the electric motor. The heated spots and their intensities change. Most defects resulting in the machine downtime are related to heating, being either their cause or a consequence. Immediate temperatures on the electric motor can be measured either by built-in sensors or via imaging showing the temperature field on the machine surface - thermal imagery (Bernat, 2006). What we are interested in practice is the magnitude and distribution of heat losses on the motor in a stable condition. These are immediate heat losses, i.e. time-independent losses. The heat losses are caused by energy lost on the stator and rotor winding. They depend on the stator winding resistance. This energy is emitted in the form of thermal energy causing stator winding warming. The temperature increase must not exceed the temperature corresponding to the winding insulation resistance (Bartoš, 2006).

When monitoring the temperature changes on the electric motor in dependence on time, air temperature and relative humidity were recorded over a period of 112 minutes. Arithmetical means of these values at different regulations are shown in Tab. I.

At the beginning, we observed temperature changes on the surface of the asynchronous

I: Average temperature and relative humidity of the ambient environment

\begin{tabular}{lcc}
\hline & Air temperature [ $\left.{ }^{\circ} \mathbf{C}\right]$ & Relative humidity [\%] \\
\hline Control valve & 26.8 & 46.6 \\
Frequency converter & 29.5 & 46.8 \\
\hline
\end{tabular}

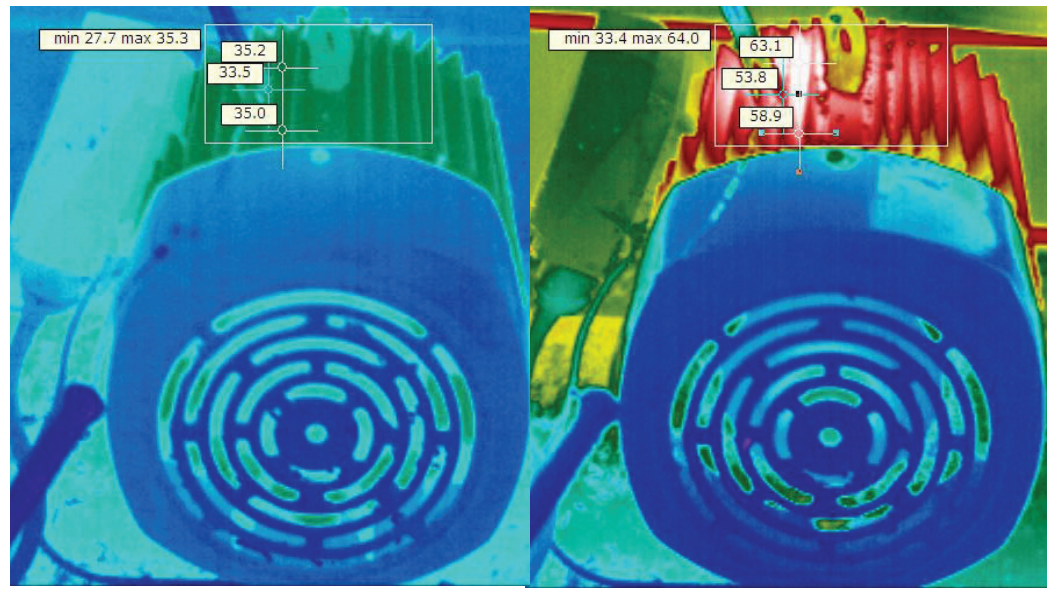

1: Thermal image of the electric motor with vacuum regulation using the control valve [Kudèlka]

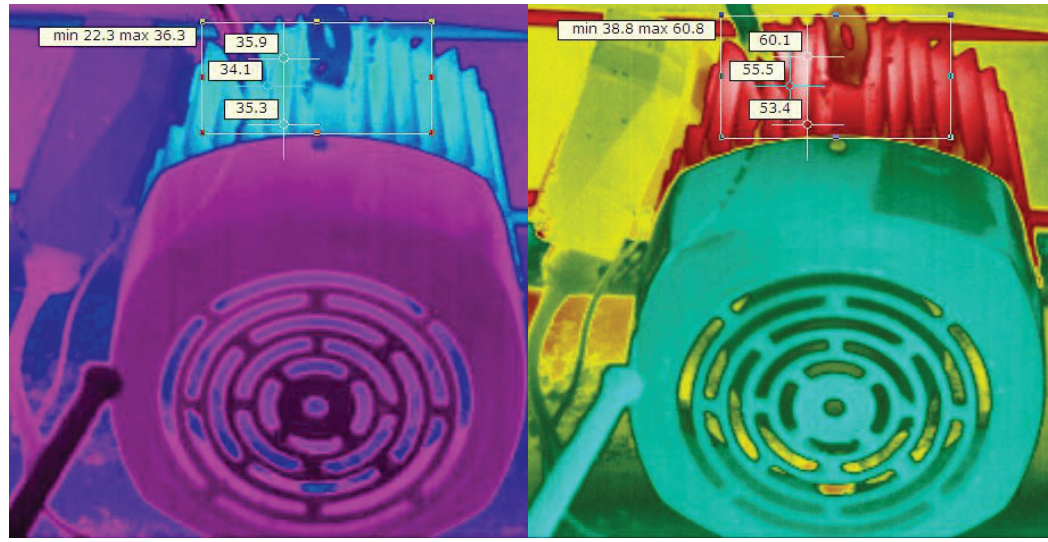

2: Thermal image of the electric motor with vacuum regulation using the frequency converter [Kudèlka] 
motor with vacuum regulation using a control valve. The thermal imaging camera FLIR E320 measured the temperature of the electric motor and the temperatures were recorded by a touch thermometer at two-minute intervals. The temperatures of the predefined reference surface (making sure that the direction of the notional infrared radiation vector is perpendicular to the thermal camera sensor) were evaluated by the QuickReport software. Images evaluated at the time of 0 minutes and 112 minutes (see Fig. 1) clearly indicate increased average temperatures of zones where the average temperature of the monitored surface $\left(34.0^{\circ} \mathrm{C}\right)$ rose to the average temperature of $53.5^{\circ} \mathrm{C}$. Maximum temperature at the time of 112 minutes amounted to $64{ }^{\circ} \mathrm{C}$, whereas starting from minute 88 the temperatures were not rising any more.

Vacuum in the air pipe was then regulated by the frequency converter. The identical measurement and temperature recording was conducted.
The initial average temperature of the reference surface was $33.8{ }^{\circ} \mathrm{C}$. The average temperature of the monitored surface after 112 minutes of machine operation increased to $53.6^{\circ} \mathrm{C}$ and the maximum temperature of the reference surface amounted to $60.8{ }^{\circ} \mathrm{C}$ (Fig. 2).

Courses of average temperature changes of the monitored reference zones at various vacuum regulations of the milking machine are shown in Fig. 3. The calculations indicate that the temperature increase is best described by the quadratic function. As indicated by Fig. 3, the quadratic function determination coefficients $\left(R^{2}\right)$ range within an interval of $R^{2}=0.98-0.99$. Therefore, the determination coefficient values are high and it may be concluded that the development trend calculated by means of the quadratic functions over the relevant time interval (112 minutes) is conclusive. The record of quadratic functions shown in Fig. 3 also shows that there is a more abrupt increase in the electric motor temperatures

The average temperature rise at different controls of vacuum

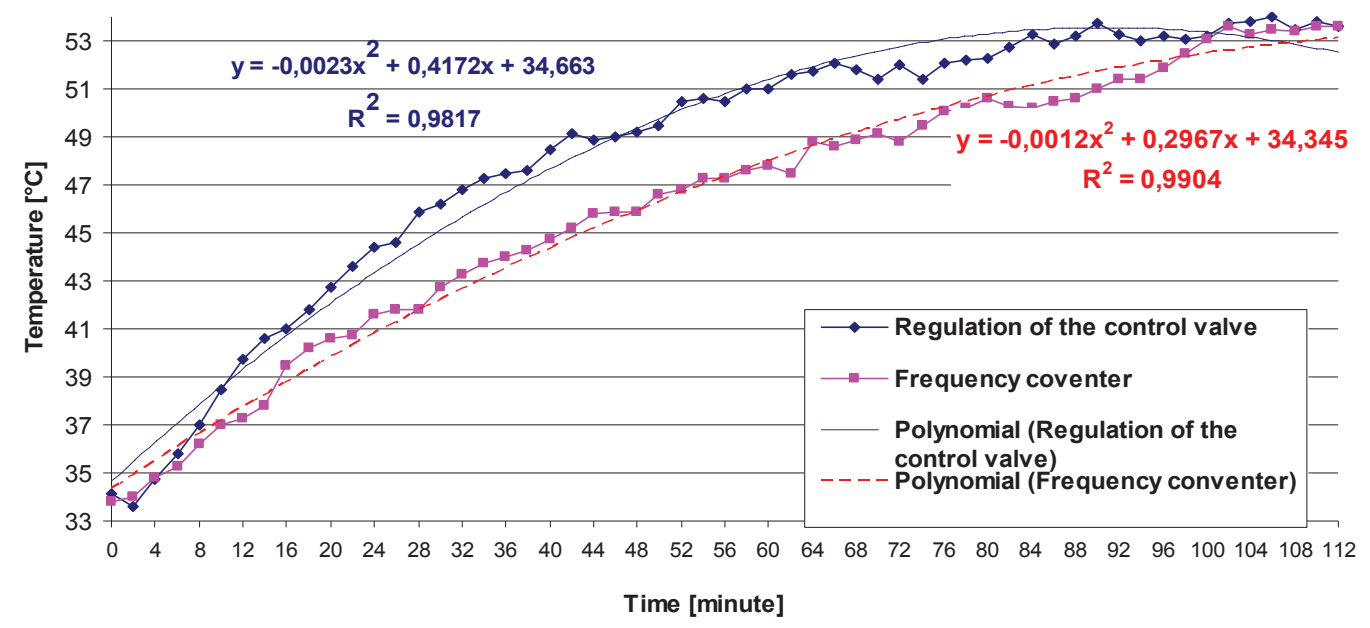

3: Average changes in temperatures of the reference surface of the electric motor at different controls

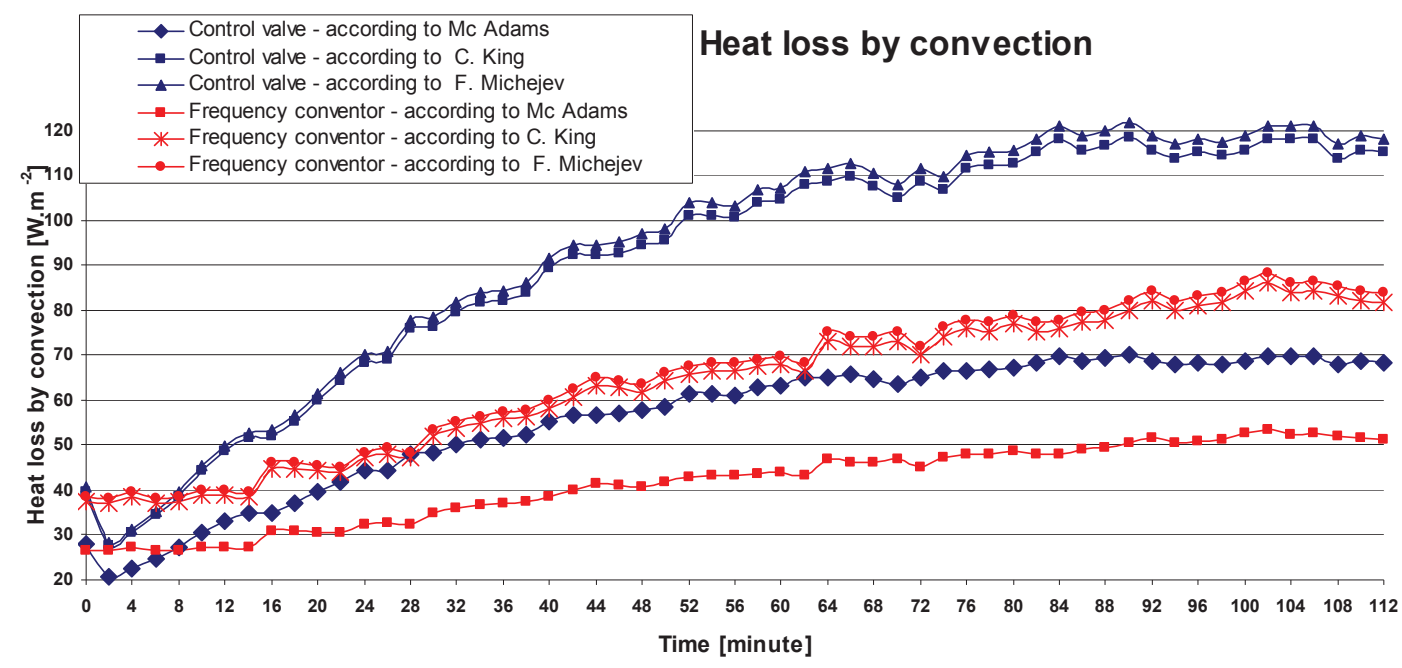

4: Specific heat loss by convection 
when the vacuum is regulated by the control valve as compared to regulation employing the frequency converter.

The course of immediate heat losses caused by convection calculated according to (5) is described in Fig. 4. Blue curves show the course of immediate heat losses through convection at vacuum regulation by the control valve. Red curves describe the course of heat losses at the electric motor control by the frequency converter. Values shown in Fig. 4 also indicate that the heat losses by convection are, as expected, higher at full operation of the electric motor if the ambient conditions are comparable. It my also be stated that the heat losses at the control valve regulation do not increase from minute 88 after starting the machine. The increase of heat losses when the frequency converter is used is gradual and stops from minute 102 of the electric motor operation. The highest values of calculated specific heat losses by convection are shown in Tab. II.

Courses of the calculated heat losses caused by radiation monitored in dependence on time according to (6) are described in Fig. 5. The graph in the picture indicates that specific heat losses by radiation at the frequency converter control increase gradually up to minute 102 and are defined by the quadratic equation: $y=-0.012 x^{2}+2.30 x+13.47$ with a reliability coefficient of $R^{2}=0.98$. Heat losses by radiation at full output of the electric motor increase up to minute 88. They are defined by the second order polynomial equation $\left(y=-0.003 x^{2}+0.9655 x+18.783\right)$ with a reliability coefficient of $R^{2}=0.99$. The highest calculated heat loss values are shown in Tab. II.

It was calculated that the size of the reference surface of passive cooling of the electric motor, which was measured by the thermal camera, equals $0.0325 \mathrm{~m}^{2}$. The course of total specific heat losses on the reference surface depending on time, at various regulations, is calculated according to (7). It is shown in Fig. 6. The graph shows that the vacuum control in the milking machine via the frequency converter results in generally lower heat losses as compared to the machine working at full power input. Maximum heat losses on the electric motor according to Mc Adams, King and Michejev are shown in Tab. II.

Thermal radiation losses

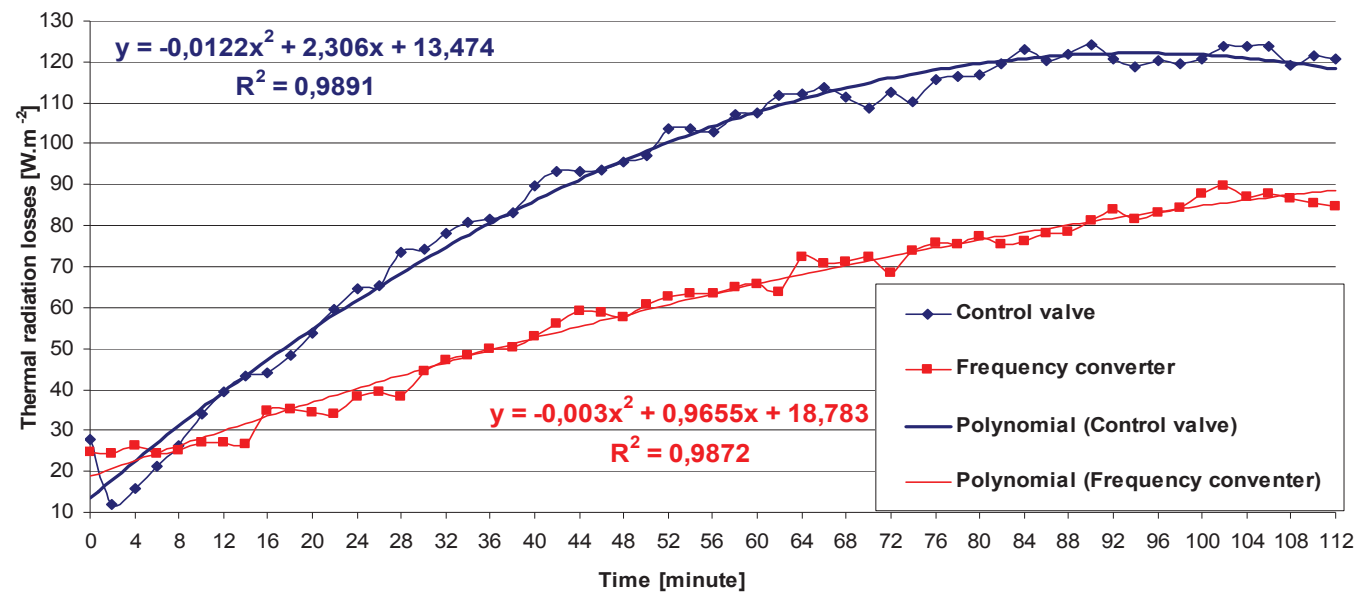

5: Specific heat losses caused by radiation

Total heat loss to the reference surface of electric motor

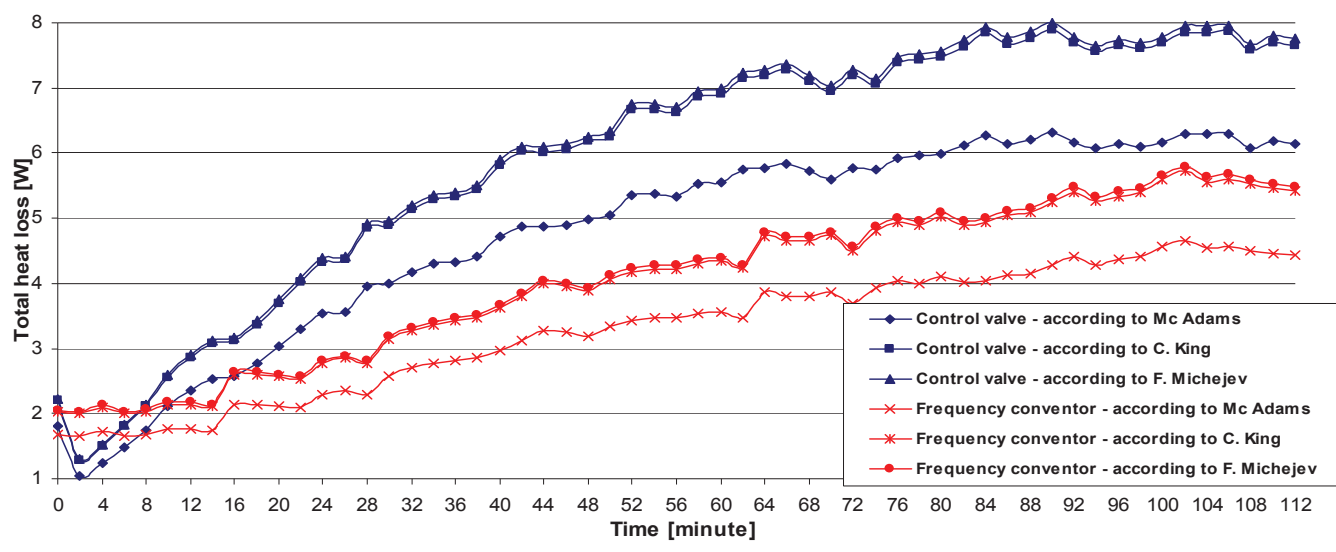

6: Total heat losses on the monitored reference surface 
II: Specific and total heat losses of the reference surface

\begin{tabular}{|c|c|c|c|c|c|c|}
\hline & \multicolumn{2}{|c|}{ Acc. to Mc Adams } & \multicolumn{2}{|c|}{ Acc. to King } & \multicolumn{2}{|c|}{ Acc. to Michejev } \\
\hline & $\begin{array}{c}\text { Control } \\
\text { valve }\end{array}$ & $\begin{array}{l}\text { Frequency } \\
\text { converter }\end{array}$ & $\begin{array}{c}\text { Control } \\
\text { valve }\end{array}$ & $\begin{array}{l}\text { Frequency } \\
\text { converter }\end{array}$ & $\begin{array}{c}\text { Control } \\
\text { valve }\end{array}$ & $\begin{array}{r}\text { Frequency } \\
\text { converter }\end{array}$ \\
\hline $\begin{array}{l}\text { Specific heat losses by convection } \\
\text { for average temperature }\left[\mathrm{W} \cdot \mathrm{m}^{-2}\right]\end{array}$ & 69.90 & 53.58 & 118.59 & 86.05 & 121.74 & 88.33 \\
\hline $\begin{array}{l}\text { Specific heat losses by radiation for average } \\
\text { temperature }\left[W \cdot m^{-2}\right]\end{array}$ & 123.94 & 89.86 & 123.94 & 89.86 & 123.94 & 89.86 \\
\hline Total specific heat losses [W.m²] & 193.84 & 143.44 & 243.53 & 175.91 & 245.68 & 178.19 \\
\hline Total heat losses for the relevant surface [W] & 6.2998 & 4.6618 & 7.914725 & 5.717075 & 7.9846 & 5.791175 \\
\hline
\end{tabular}

Provided that the average temperature of the reference surface of the passive cooling cladding of the electric motor at the control valve regulation equals $5.5{ }^{\circ} \mathrm{C}$, total heat losses of the reference surface according to Mc Adams will be $6.30 \mathrm{~W}$, according to King $7.91 \mathrm{~W}$ and according to Michejev 7.98 W. When the electric motor was controlled by the frequency converter, the average temperature of the reference surface of the electric motor increased to $53.6^{\circ} \mathrm{C}$. However, the total heat losses dropped: according to Mc Adams to 4.66 $\mathrm{W}$, according to King to $5.72 \mathrm{~W}$ and according to Michejev to $5.79 \mathrm{~W}$.

\section{CONCLUSIONS}

The assessment of temperatures measured on the reference surface recorded by the thermal camera Model FLIR E320 using the QuickReport programme and the statistical method of regression analysis indicate that the traditional vacuum regulation by the control valve results in a more abrupt temperature increase as compared with the regulation by the frequency converter Siemens Model Sinamics G120P BT. Average temperature changes on the reference surface during 112 minutes of the operation of the milking machine electric motor in HOD Jabloňov (vacuum regulation by the control valve) are described by the quadratic equation $=-0.0023 \mathrm{x}^{2}+0.4172 \mathrm{x}+34.663$. The determination coefficient $\left(\mathrm{R}^{2}\right)$ equals 0.98 . The average temperature change on the surface of the electric motor if the regulation is ensured by the frequency converter Siemens Model Sinamics G120P BT is defined by the regression function $y=-0.0012 x^{2}+0.2967 x+34.345$, where the determination coefficient $\left(R^{2}\right)=0.99$.

The temperature measurement using thermal imaging in HOD Jabloňov and the calculations of specific heat losses using similarity relations confirmed that the electric motor supply via the frequency converter results in a change in the distribution of thermal flows in the individual parts of the electric motor. However, the immediate heat losses on the reference surface of the electric motor in a stabilised condition are lower if the regulation is ensured by the frequency converter as opposed to the classic regulation via the control valve. Therefore, it may be concluded that the stator winding of the electric motor does not become overheated, which is otherwise one of the factors of electric motor defects.

\section{SUMMARY}

Thefrequency converters control the operation of the asynchronous electric motorin milking machine vacuum pumps so that the actual delivery of the vacuum pumps equals the amount of air sucked into the vacuum pipe. The motor power supply via the frequency converter results in a number of negative phenomena. The paper deals with the motor heating and heat losses on the surface of the electric motor at various vacuum controls of the milking machine. The aim of the paper is to determine the immediate specific heat flows on the surface of the milking machine electric motor during milking at regulation using a control valve and regulation via a frequency converter and to compare the resulting values. The specific heat flows were determined by means of a non-traditional method of temperature field measurement by a thermal camera. This is a quick informative method which, to a certain extent, replaces the heat flow calculation using criterial equations. Use was made of a milking machine installed in the cooperative Hospodářské obchodní družstvo (HOD) in Jabloňov. The temperature changes measurement and the subsequent determination of temperature dependence and heat flows at various vacuum controls of the asynchronous motor were based on a digital thermometer Omega HHll with a touch sensor (measurement accuracy $\pm 0.1{ }^{\circ} \mathrm{C}$ ) and thermal camera FLIR E320. The assessment of temperatures measured on the reference surface recorded by the thermal camera FLIR E320 using the QuickReport programme and the statistical method of regression analysis indicate that the traditional vacuum regulation by the control valve results in a more abrupt temperature increase as compared with the regulation by the frequency converter Siemens Sinamics G120P BT. 
The temperature measurement using thermal imagery in HOD Jabloňov and the calculations of specific heat losses using similarity relations confirm that if the electric motor is supplied by means of a frequency converter, a change occurs in the distribution of heat flows in the individual parts of the electric motor. However, the immediate heat losses on the reference surface of the electric motor in a stabilised condition are lower at the frequency converter control compared to the classic regulation using a control valve. Therefore, it can be stated that the stator winding of the electric motor does not become overheated, which is otherwise one of the factors why the electric motor fails.

\section{Acknowledgement}

This project is implemented with the support of the Internal Grant Agency of the Faculty of Agronomy, Mendel University in Brno, TP 8/2014. The project was also employed as part of the innovation of the subject taught in the field of TO, ZS, ARI system for the management of pilot biomass stations Biomass and bioenergy transformation (IN2140331).

\section{REFERENCES}

BARTOŠ, V. 2006. Mèrení na elektrických strojích. 2. vyd. Plzeň: Západočeská univerzita v Plzni.

BAŠTA, J. 2000. Otopná tẻlesa. STP, p. 38-39.

BERNAT, P. 2006. Negativní vlivy méniču frekvence na asynchronní motor. Ostrava. Disertační práce. Ostrava: FEI, VŠB-TU Ostrava.

BERCKMANS, D. 2004. Automatic Online Monitoring of Animals by Precision Livestock Farming. In: Proceedings of the Congress of the International Society for Animal Hygiène-Animal Production In Europe: The Way Forward In A Changing World. Saint-Malo, France, 11-13 October 2004. 27-30.

ČSN ISO 5707. 1998. Dojící zař́izení: Konstrukce a provedení. 2. dopl. vydání. Praha: Technické normy ČSN.

DOLEŽAL, O. et al. 2000. Mléko, dojení, dojirny. 1. vyd. Praha: Agrospoj, 2000.

FRYČ, J. 2000, Regulace podtlaku a energetická náročnost soustroji vacuum pumps dojicích strojü. Habilitační práce. Brno: Mendelova univerzita $v$ Brně.

GRODA, B., VÍTĚZ, T. 2008. Termomechanika I.

1. Vyd. Brno: Mendelova zemědělská a lesnická univerzita.
KOLARČÍK, K., VRTEK M. 2002. Možnosti úspor energie, prí výrobě, rozvodu a spotřebè stlačeného vzduchu v České republice. 1. vyd. Praha: Technologické centrum AV ČR.

KUDĚLKA, J, FRYČ, J. 2012. Řízení činnosti vývěvy dojícího stroje. In: MendelNet 2012 - Proceedings of International Ph.D. Students Conference, p. 11011107.

PǨIKRYL, M. et al. 1997. Technologická zařízení staveb ¿̌ivocišné výroby. Praha: Tempo Press II.

REINEMANN, DOUGLAS, J. 2005. The history of vacuum regulation technology. In: The 2007 International Standards for Milking Machine Installations and Automatic Milking Installations. Madison, Wisconsin: University of WisconsinMadison, Milking Research and Instruction Laboratory, 124-132.

STALEY, D. O. 1972. Effective Atmospheric Emissivity under Clear Skies. J. Appl. Meteor., 11: 349-356.

STRÖBEL, U. 2013. Development of a Control System for the Teat-End Vacuum in Individual Quarter Milking Systems., In: Sensors 2013, 13, 7633-7651.

Jan Kudělka: jan.kudelka@mendelu.cz Jiři Fryč: jiri.fryc@mendelu.cz Petr Trávníček: petr.travnicek@mendelu.cz 